\title{
Evolution of Fusarium oxysporum f. sp. vasinfectum Races Inferred from Multigene Genealogies
}

\author{
Kerstin Skovgaard, Helgard I. Nirenberg, Kerry O’Donnell, and Søren Rosendahl
}

First and fourth authors: Department of Mycology, University of Copenhagen, Oester Farimagsgade 2D, 1353 Copenhagen K, Denmark; second author: Institut für Pflanzenvirologie, Mikrobiologie und biologische Sicherheit, Biologische Bundesanstalt für Land- und Forstwirtschaft, Koenigin-Luise-Strasse 19, 14195 Berlin, Germany; and third author: Microbial Properties Research Unit, National Center for Agricultural Utilization Research, U.S. Department of Agriculture, Agricultural Research Service, 1815 North University Street, Peoria, IL.

Accepted for publication 11 September 2001.

\begin{abstract}
Skovgaard, K., Nirenberg, H. I., O'Donnell, K., and Rosendahl, S. 2001. Evolution of Fusarium oxysporum f. sp. vasinfectum races inferred from multigene genealogies. Phytopathology 91:1231-1237.

Fusarium wilt of cotton is a serious fungal disease responsible for significant yield losses throughout the world. Evolution of the causal organism Fusarium oxysporum f. sp. vasinfectum, including the eight races described for this specialized form, was studied using multigene genealogies. Partial sequences of translation elongation factor (EF-1 $\alpha)$, nitrate reductase (NIR), phosphate permase (PHO), and the mitochondrial small subunit (mtSSU) rDNA were sequenced in 28 isolates of $F$. oxysporum f. sp. vasinfectum selected to represent the global genetic diversity of this forma specialis. Results of a Wilcoxon Signed-Ranks Templeton test indicated that sequences of the four genes could be

combined. In addition, using combined data from EF- $1 \alpha$ and mtSSU rDNA, the phylogenetic origin of $F$. oxysporum f. sp. vasinfectum within the $F$. oxysporum complex was evaluated by the Kishino-Hasegawa likelihood test. Results of this test indicated the eight races of $F$. oxysporum f. sp. vasinfectum appeared to be nonmonophyletic, having at least two independent, or polyphyletic, evolutionary origins. Races 3 and 5 formed a strongly supported clade separate from the other six races. The combined EF-1 $\alpha$, NIR, PHO, and mtSSU rDNA sequence data from the 28 isolates of $F$. oxysporum f. sp. vasinfectum recovered four lineages that correlated with differences in virulence and geographic origin: lineage I contained race 3, mostly from Egypt, and race 5 from Sudan; lineage II contained races 1, 2, and 6 from North and South America and Africa; lineage III contained race 8 from China; and lineage IV contained isolates of races 4 and 7 from India and China, respectively.
\end{abstract}

Fusarium wilt is an important limiting factor in the production of cotton throughout major producing areas in Australia, Africa, Asia, and North and South America $(9,10,30)$. The causal organism, Fusarium oxysporum Schlechtend.:Fr. f. sp. vasinfectum (Atk.) W.C. Snyder \& H.N. Hans., invades the host through the taproots behind the root tip. The combined effect of fungal metabolites and the production of lipoidal substances by the host in response to infection may lead to occlusion of the vascular tissue, resulting in wilt of the cotton plant $(14,29)$.

Plant pathogenic isolates of $F$. oxysporum are separated into formae speciales based on their pathogenicity to one or more host plants. Although more than $75 \mathrm{~F}$. oxysporum formae speciales have been described (4), the evolutionary origin of only a few of these has been investigated using discrete DNA sequence data. Strains of F. oxysporum f. sp. cubense, causing Panama disease of banana, and $F$. oxysporum f. sp. melonis have been shown to be polyphyletic (26). Similarly, F. oxysporum f. spp. asparagi, dianthi, gladioli, and lini appear to have multiple evolutionary origins within the $F$. oxysporum complex (7). Baayen et al. (7) reported that $F$. oxysporum f. spp. lilii and tulipae appear to have a monophyletic origin. Although monophyly of $F$. oxysporum f. sp. vasinfectum has not been tested directly, random amplified polymorphic DNA (RAPD) (6) and restriction fragment length polymorphism (RFLP) analyses of rDNA and mtDNA (11) indicated that strains of $F$. oxysporum $\mathrm{f}$. sp. vasinfectum from a worldwide collection are genetically diverse.

Corresponding author: K. Skovgaard; E-mail address: kerstins@bot.ku.dk

Publication no. P-2001-1025-01R

(C) 2001 The American Phytopathological Society
Eight races have been identified within $F$. oxysporum f. sp. vasinfectum based on pathogenicity tests on a number of Gossypium spp. (2,5,9,15). Furthermore, alfalfa, soybean, and tobacco are used to differentiate races 1,5 , and 6 , which share pathogenicity toward upland cotton, G. hirsutum (3). Pathogenicity tests, however, are time consuming and require careful standardization of procedures and environmental conditions because different inoculation techniques change aggressiveness of $F$. oxysporum $f$. sp. vasinfectum toward cotton (16). Genetic markers have been sought to provide a more reproducible and less labor-intensive method to identify races of $F$. oxysporum $\mathrm{f}$. sp. vasinfectum and other formae speciales $(18,22)$. However, if the pathogenicity tests used to characterize the race is flawed in some manner, the molecular markers will be tied to an ambiguous phenotype and therefore of no use. Cellular fatty acid and RAPD data have been used to differentiate races of $F$. oxysporum $\mathrm{f}$. sp. vasinfectum into three clusters (i.e., A, B, and C) in which races 1,2 , and 6 correspond to group $\mathrm{A}$, race 4 to group $\mathrm{B}$, and races 3 and 5 to group $\mathrm{C}$ $(6,13)$. However, these studies did not include strains of race 7 and 8 and they did not attempt to resolve phylogenetic relationships of $F$. oxysporum f. sp. vasinfectum within the $F$. oxysporum complex. Detailed knowledge of the genetic variation and evolutionary origins and relationships of formae speciales within the F. oxysporum complex provides an important framework for developing more effective plant disease control strategies and breeding programs, especially if strains of a forma specialis are nonmonophyletic.

Analyses of DNA sequences of several mostly single copy nuclear genes have recently been used to study evolutionary relationships among closely related and often "cryptic" fungal species $(12,20,27)$. This phylogenetic approach based on the con- 
cordance of multiple gene genealogies is an effective tool for reconstructing the evolutionary history of pathogenic fungi (31). The present study was undertaken to determine to what extent DNA sequences from portions of four genes could be used to distinguish the eight races of $F$. oxysporum $\mathrm{f}$. sp. vasinfectum and to provide the first direct test of $F$. oxysporum f. sp. vasinfectum monophyly.

\section{MATERIALS AND METHODS}

Fungal isolates. Twenty-eight isolates of $F$. oxysporum f. sp. vasinfectum from a worldwide collection from four continents were used in this study (Table 1 ). Twenty four of the $F$. oxysporum f. sp. vasinfectum isolates have been tested for pathogenicity in a greenhouse and were classified as races based on their symptoms on test cultivars of G. barbadense, G. hirsutum, G. arboreum, and Nicotiana tabaci. As differentials, the following cultivars were used: G. barbadense cvs. Sakel and Ashmoni, G. hirsutum cv. Acala, G. arboreum cv. CG 17, and N. tabaci cvs. Gold Dollar and Burley 5. Detailed information of the pathogenicity will be published later (H. I. Nirenberg, unpublished data) (Table 1). All isolates are stored cryogenically at $-175^{\circ} \mathrm{C}$ in the Agricultural Research Service Culture Collection (NRRL) at the National Center for Agricultural Utilization Research, Peoria, IL. F. oxysporum f. sp. vasinfectum strains were grown in yeast-malt broth (per liter: $3 \mathrm{~g}$ of yeast extract, $3 \mathrm{~g}$ of malt extract, $5 \mathrm{~g}$ of peptone, and $20 \mathrm{~g}$ of glucose) for 2 to 3 days at room temperature on an orbital shaker $(200 \mathrm{rpm})$. Mycelia were harvested and total genomic DNA was extracted using a CTAB (hexadecyltrimethlammonium bromide; Sigma Chemical Co., St. Louis) protocol described previously (24).

Amplification and sequencing. Fragments of three nuclear genes, translation elongation factor (EF-1 $\alpha, 652 \mathrm{bp})$, nitrate reductase (NIR, $507 \mathrm{bp}$ ), and phosphate permase (PHO, $612 \mathrm{bp}$ ), and a

TABLE 1. Strains of Fusarium oxysporum f. sp. vasinfectum and other taxa used in this study

\begin{tabular}{|c|c|c|c|c|}
\hline Taxon and race & Source $^{\mathrm{a}}$ & Host & Origin & Reference \\
\hline F. oxysporum $\mathrm{f}$. sp. vasinfectum race $1^{\mathrm{b}}$ & BBA 66843 & Gossypium sp. & USA & ATCC $16421^{\mathrm{c}}$ \\
\hline F. oxysporum f. sp. vasinfectum race $1^{\mathrm{b}}$ & BBA 65634 & G. hirsutum & USA, CA & $(16)^{\mathrm{c}}$ \\
\hline F. oxysporum f. sp. vasinfectum race $2^{\mathrm{b}}$ & BBA 64495 & G. barbadense & Egypt & This study \\
\hline F. oxysporum f. sp. vasinfectum race $2^{b}$ & BBA 65633 & G. hirsutum & USA, CA & This study \\
\hline F. oxysporum f. sp. vasinfectum race $2^{\mathrm{b}}$ & BBA 65635 & G. hirsutum & USA, CA & This study \\
\hline F. oxysporum f. sp. vasinfectum race $2^{b}$ & BBA 65636 & G. hirsutum & USA, CA & This study \\
\hline F. oxysporum f. sp. vasinfectum race $2^{\text {b }}$ & BBA 65655 & Gossypium sp. & USA & This study \\
\hline F. oxysporum f. sp. vasinfectum race $2^{\mathrm{b}}$ & BBA 66844 & Gossypium sp. & USA & ATCC $16611^{\mathrm{c}}$ \\
\hline F. oxysporum f. sp. vasinfectum race $2^{\mathrm{b}}$ & BBA 69405 & G. barbadense & Peru & This study \\
\hline F. oxysporum f. sp. vasinfectum race $2^{b}$ & BBA 65653 & Gossypium sp. & USA, AL & This study \\
\hline F. oxysporum f. sp. vasinfectum race $3^{\mathrm{b}}$ & BBA 67521 & G. hirsutum & Egypt & This study \\
\hline F. oxysporum f. sp. vasinfectum race $3^{b}$ & BBA 66845 & Gossypium sp. & Egypt & ATCC $16612^{c}$ \\
\hline F. oxysporum $\mathrm{f}$. sp. vasinfectum race $3^{\mathrm{b}}$ & BBA 64496 & G. barbadense & Egypt & $(23)^{\mathrm{c}}$ \\
\hline F. oxysporum f. sp. vasinfectum race $3^{\mathrm{b}}$ & BBA 62374 & Gossypium sp. & Egypt & This study \\
\hline F. oxysporum f. sp. vasinfectum race $3^{\mathrm{b}}$ & BBA 62375 & Gossypium sp. & Egypt & This study \\
\hline F. oxysporum f. sp. vasinfectum race $3^{\mathrm{b}}$ & BBA 69712 & Gossypium sp. & China & This study \\
\hline F. oxysporum f. sp. vasinfectum race $4^{\mathrm{b}}$ & BBA 69519 & Gossypium sp. & India & This study \\
\hline F. oxysporum f. sp. vasinfectum race 4 & BBA 69520 & Gossypium sp. & India & This study \\
\hline F. oxysporum f. sp. vasinfectum race 4 & BBA 69521 & Gossypium sp. & India & This study \\
\hline F. oxysporum f. sp. vasinfectum race 4 & BBA 65934 & G. arboreum & Unknown & This study \\
\hline F. oxysporum f. sp. vasinfectum race $4^{\mathrm{b}}$ & BBA 66846 & Gossypium sp. & India & ATCC $16613^{c}$ \\
\hline F. oxysporum f. sp. vasinfectum race 4 & BBA 69518 & Gossypium sp. & India & This study \\
\hline F. oxysporum f. sp. vasinfectum race $5^{\mathrm{b}}$ & BBA 65650 & G. barbadense & Sudan & $(13)^{\mathrm{c}}$ \\
\hline F. oxysporum f. sp. vasinfectum race $5^{\mathrm{b}}$ & BBA 65654 & G. barbadense & Sudan & $(13)^{\mathrm{c}}$ \\
\hline F. oxysporum f. sp. vasinfectum race $6^{\mathrm{b}}$ & BBA 66847 & Gossypium sp. & Brazil & ATCC $36198^{c}$ \\
\hline F. oxysporum f. sp. vasinfectum race $7^{\mathrm{b}}$ & BBA 69050 & Gossypium sp. & China & This study \\
\hline F. oxysporum f. sp. vasinfectum race $7^{\mathrm{b}}$ & BBA 69716 & Gossypium sp. & China & $(9)^{c}$ \\
\hline F. oxysporum f. sp. vasinfectum race $8^{\mathrm{b}}$ & BBA 69711 & Gossypium sp. & China & $(9)^{c}$ \\
\hline F. oxysporum f. sp. melonis & NRRL 26178 & Cucumis melo & USA, MD & $(26)^{d}$ \\
\hline F. oxysporum f. sp. cubense & NRRL 25609 & Musa sp. & Malawi & $(26)^{d}$ \\
\hline F. oxysporum f. sp. radicis lycopersici & NRRL 26033 & Solanum esculentum & USA, FL & $(26)^{d}$ \\
\hline F. oxysporum $\mathrm{f}$. sp. radicis lycopersici & NRRL 26380 & Solanum esculentum & USA, FL & $(26)^{d}$ \\
\hline F. oxysporum f. sp. radicis lycopersici & NRRL 26381 & Solanum esculentum & USA, FL & $(26)^{d}$ \\
\hline F. oxysporum f. sp. dianthi & NRRL 28906 & Dianthus caryophyllus & Australia & $(7)^{d}$ \\
\hline F. oxysporum f. sp. pisi & NRRL 29870 & Pisum sativum & USA & This study \\
\hline F. oxysporum f. sp. cucumerinum & NRRL 26437 & Cucumis sativus & USA, SC & This study \\
\hline F. oxysporum f. sp. dianthi & NRRL 26960 & Dianthus caryophyllus & The Netherlands & $(7)^{d}$ \\
\hline F. oxysporum f. sp. momordicae & NRRL 26748 & Momordica charantia & Japan & This study \\
\hline F. oxysporum f. sp. spinaciae & NRRL 26876 & Spinacea oleracea & USA, AK & $(7)^{\mathrm{d}}$ \\
\hline F. oxysporum f. sp. lilii & NRRL 28395 & Lilium sp. & Italy & $(7)^{d}$ \\
\hline F. oxysporum f. sp. albedinis & NRRL 26622 & Phoenix dactylifera & Morocco & This study \\
\hline F. oxysporum f. sp. tulipae & NRRL 26954 & Tulipa $\times$ gesneriana & The Netherlands & $(7)^{\mathrm{d}}$ \\
\hline Fusarium sp. (outgroup) & NRRL 25052 & Pinus strobus & Canada & This study \\
\hline
\end{tabular}

${ }^{a}$ BBA = Biologische Bundesanstalt für Land-und Forstwirtschaft, Berlin, Germany. NRRL = National Center for Agricultural Utilization Research, Peoria, IL.

b Pathogenicity tested at BBA.

c Strain received with race identified.

d Sequence data from this study were aligned with published translation elongation factor and mitochondrial small subunit rDNA sequences. 
portion of the mitochondrial small subunit (mtSSU, $674 \mathrm{bp}$ ) rDNA were sequenced. Amplification and sequencing primers used in this study are listed in Table 2. Polymerase chain reaction (PCR) amplification and sequencing of the mtSSU rDNA and the EF- $1 \alpha$ gene was performed using reagents and primers described previously $(25,32)$. PCR amplification of NIR and PHO was performed in a thermocycler (PTC-100; MJ Research, Watertown, MA) using the following program: $1 \mathrm{~min}$ initial denaturing at $97^{\circ} \mathrm{C}$, followed by 35 cycles of $30 \mathrm{~s}$ denaturing at $96^{\circ} \mathrm{C}, 1 \mathrm{~min}$ annealing at $50^{\circ} \mathrm{C}$ for $\mathrm{PHO}$ and $60^{\circ} \mathrm{C}$ for NIR, $1 \mathrm{~min}$ at $72^{\circ} \mathrm{C}$, and a final extension of $10 \mathrm{~min}$ at $72^{\circ} \mathrm{C}$, followed by cooling to $4^{\circ} \mathrm{C}$. Purified PCR products (GeneClean II, Q-Biogene, Carlsbad, CA) and internal sequencing primers were used for cycle sequencing reactions with the fluorescent-labeled BigDye kit (Perkin-Elmer, Foster City, CA). The reaction products were purified by gel filtration through Sephadex G-50 (Pharmacia, Piscataway, NJ) and run on an automated DNA sequencer (Model 377; Applied Biosystems, Perkin-Elmer). Maps indicating the locations of NIR and PHO amplification and sequencing primers are shown in Figure 1.

Phylogenetic analysis. EF- $1 \alpha$, mtSSU rDNA, PHO, and NIR sequences were aligned and edited in Sequencher version 3.0 (GeneCodes, Ann Arbor, MI). All of the sequences generated in the present study have been deposited as GenBank Accession Nos. AF362139 to AF362260. All phylogenetic analyses were performed using parsimony (PAUP 4.0b.4a; Sinauer Associates Inc., Sunderland, MA; written by D. L. Swofford, Smithsonian Institute, Washington, D.C.) including the nonparametric Wilcoxon Signed-Ranks (WS-R) Templeton combinability test. The $F$. oxysporum f. sp. vasinfectum sequences from this study were aligned with several published mtSSU rDNA and EF-1 $\alpha$ sequences obtained from GenBank (Table 1). Heuristic searches used 1,000 random addition sequences with tree bisection-reconnection branch swapping on. All characters were equally weighted, and alignment gaps were treated as missing data. Support for the internal nodes of the most parsimonious trees (MPTs) was assessed by 1,000 parsimony bootstrap replications, and decay indices were calculated using AutoDecay 4.0 (written by T. Eriksson, Stockholm University, Stockholm, Sweden). The Kishino-Hasegawa (K-H) likelihood test implemented in PAUP was used to test the monophyly of $F$. oxysporum $\mathrm{f}$. sp. vasinfectum by comparing the tree-lengths of the unconstrained MPTs with those in which monophyly of selected races of $F$. oxysporum $\mathrm{f}$. sp. vasinfectum was enforced.

\section{RESULTS}

Of the 28 isolates of $F$. oxysporum $\mathrm{f}$. sp. vasinfectum used in this study, maximum parsimony analysis of the aligned sequences identified five unique EF- $1 \alpha$ and PHO haplotypes (Fig. 2A and D), four NIR haplotypes (Fig. 2C), and only two mtSSU rDNA haplotypes (Fig. 2B). Sequences of EF-1 $\alpha$ and mtSSU rDNA contributed most of the phylogenetic signal (seven and five parsimony-informative characters or synapomorphies, respectively) followed by PHO and NIR (four and two synapomorphies, respectively; one in the coding and noncoding region of NIR; Fig. 1). Trees based on parsimony analysis of the sequence data from each of the four loci, rooted with a sequence of Fusarium sp. (NRRL 25052) by the outgroup method, are shown in Figure 2. The same underlying phylogeny appears to have been sampled in each of the gene genealogies, because races 3 and 5 formed a clade in all four gene trees independent of the other races that were resolved as a separate clade in all but the poorly resolved NIR gene tree (Fig. 2C). No homoplasy was observed because all four trees have a consistency index of 1.0.

Results of the Templeton WS-R combinability test implemented in PAUP indicated that the sequences of the four genes could be analyzed as a combined data set $(P=1$ when each of the four data sets was constrained to the $70 \%$ bootstrap consensus of the other partitions). Parsimony analysis of the combined sequence data from the 28 strains of $F$. oxysporum f. sp. vasinfectum (18 synapomorphies, 20 autapomorphies) yielded a single MPT 38 steps in length (Fig. 3). The $F$. oxysporum f. sp. vasinfectum isolates were resolved as four distinct lineages (I to IV) that generally show a correlation with race and geographic origin. Lineage I (100\%

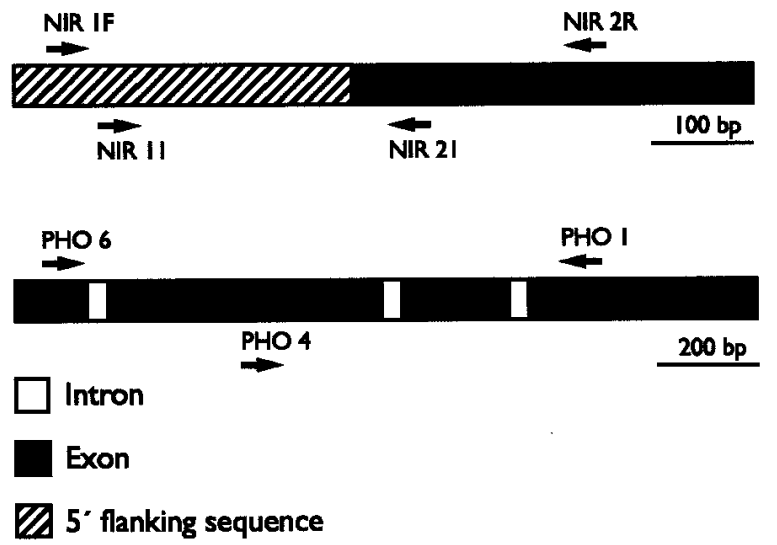

Fig. 1. Locations of amplification and sequencing primers for nitrate reductase (NIR) and phosphate permase (PHO) used in this study (Table 2). NIR (507 bp) comprising 302 bp of 5'-flanking sequence and 202 bp of exon 1 . The position of introns in PHO is based on the information from GenBank Accession No. AB011417.

TABLE 2. Primers used in this study

\begin{tabular}{|c|c|c|c|}
\hline Locus & Primer sequence & Annealing temperature & Reference \\
\hline \multicolumn{4}{|c|}{ Mitochondrial small subunit (mtSSU) } \\
\hline MS 1 & 5' CAGCAGTCAAGAATATTAGTCAATG & 50 & $(32)$ \\
\hline MS 2 & 5' GCGGATTATCGAATTAAATAAC & 55 & (32) \\
\hline MS 21 & 5' СТСТССТССТСAAGTACTGC & 55 & (24) \\
\hline \multicolumn{4}{|c|}{ Nitrate reductase (NIR) } \\
\hline NIR $1 F$ & 5' CCGCGGGATCAGACCAGAGCCC & 60 & This study \\
\hline NIR 2R & 5' TTTGGAGGTAGAGGATAAGGC & 60 & This study \\
\hline NIR 11 & $5^{\prime}$ TCATGAACCAAGCCTCAGCAG & 55 & This study \\
\hline NIR 21 & 5' GAGTTTTCAGGAATCCTTTCC & 55 & This study \\
\hline \multicolumn{4}{|c|}{ Phosphate permase (PHO) } \\
\hline PHO 1 & 5' ATCTTCTGGCGTGTTATCATG & 50 & $(27)$ \\
\hline $\mathrm{PHO} 4$ & 5' GTGCTGGAAGAAGTCTCTCC & 55 & $(27)$ \\
\hline PHO 6 & 5' GATGTGGTTGTAAGCAAAGCCC & 50 & $(27)$ \\
\hline \multicolumn{4}{|c|}{ Translation elongation factor $(\mathrm{EF}-1 \alpha)$} \\
\hline $\mathrm{EF}-1$ & 5' ATGGGTAAGGAAGACAAGAC & 50 & $(26)$ \\
\hline $\mathrm{EF}-2$ & 5' GGAAGTACCAGTGATCATGTT & 50 & $(26)$ \\
\hline EF-11 & 5' GTGGGGCATTTACCCCGCC & 55 & $(26)$ \\
\hline $\mathrm{EF}-22$ & $5^{\prime}$ AGGAACCCTTACCGAGCTC & 55 & $(26)$ \\
\hline
\end{tabular}



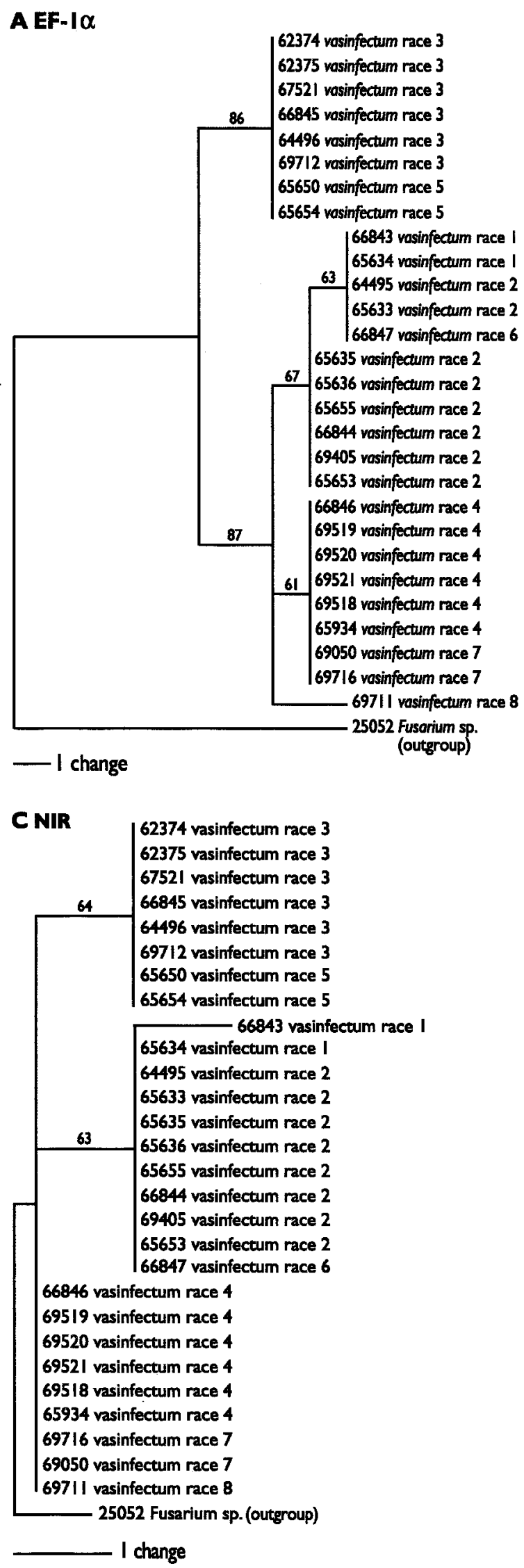

\section{B mtSSU rDNA}
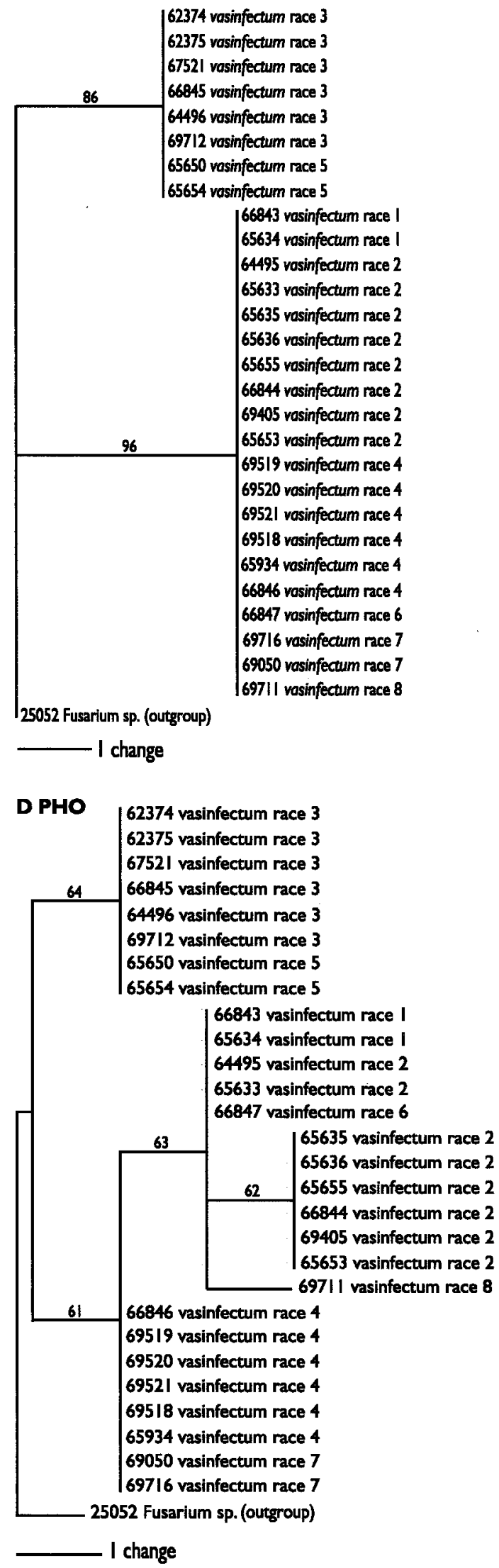

Fig. 2. Phylograms inferred from parsimony analysis of sequence data from each of the four loci rooted with a sequence of Fusarium sp. (NRRL 25052). Numbers by nodes represent bootstrap of $\geq 50 \%$ from 1,000 replications. $\mathrm{CI}=$ consistency index; RI = retention index. A, Translation elongation factor (EF- $1 \alpha$; 23 steps, CI = 1, RI = 1). B, Mitochondrial small subunit (mtSSU) rDNA (five steps, $\mathrm{CI}=1, \mathrm{RI}=1$ ). C, Nitrate reductase $(\mathrm{NIR}$; four steps, CI = 1, RI = 1). D, Phosphate permase ( $\mathrm{PHO}$; six steps, $\mathrm{CI}=1, \mathrm{RI}=1)$. 
bootstrap support) contains strains of race 3 , which except for one strain, are all from Egypt, and race 5 from Sudan, which borders Egypt. The other six races of $F$. oxysporum $\mathrm{f}$. sp. vasinfectum were divided among three lineages (II to IV) that formed a strongly supported clade ( $100 \%$ bootstrap) within the molecular phylogeny. Lineage II (84\% bootstrap) contains races 1 and 2, which are primarily from the United States, and race 6 from Brazil. Lineage III is represented by a single strain of race 8 from China. Lineage IV appears to represent a second Asian lineage, with strains of race 4 from India and race 7 from China. Using DNA sequence data, we were unable to differentiate races 3 and 5 of lineage I, some strains of races 1,2 , and 6 within lineage II, and races 4 and 7 in lineage IV. All races, except 1 and 2, were composed of genetically homogeneous groups supported by bootstrap values ranging from 62 to $100 \%$ (Fig. 3).

To examine the evolutionary origin of $F$. oxysporum f. sp. vasinfectum within the $F$. oxysporum complex, we conducted a parsimony analysis of the combined EF- $1 \alpha$ and mtSSU rDNA sequence data. Results of the Templeton WS-R combinability test indicated that these partitions could be combined ( $P=1$ constraining mtSSU rDNA to the EF- $1 \alpha 70 \%$ bootstrap consensus, and $P=1$ constraining EF- $1 \alpha$ to the mtSSU rDNA $70 \%$ bootstrap consensus). The data set included representatives of all eight races of $F$. oxysporum f. sp. vasinfectum and 11 other formae speciales (Table 1; Fig. 4). Unweighted maximum parsimony analysis of the combined data set yielded a single MPT, 36 steps in length (consistency index $=1$, and retention index $=1$ ). When strains of F. oxysporum f. sp. vasinfectum were constrained to form a monophyletic group, the constrained MPTs were significantly longer and worse than the unconstrained MPT (Table 3; K-H test, $P=$ 0.0002). The K-H test results strongly indicate that the evolutionary origin of races 3 and 5 was independent of the six other races of $F$. oxysporum f. sp. vasinfectum, indicated by the nesting of each of these races within separate strongly supported (bootstrap $=98 \%$ ) subclades within the molecular phylogeny (Fig. 4). A second constraint that forced the monophyly of races $1,2,4,6,7$,

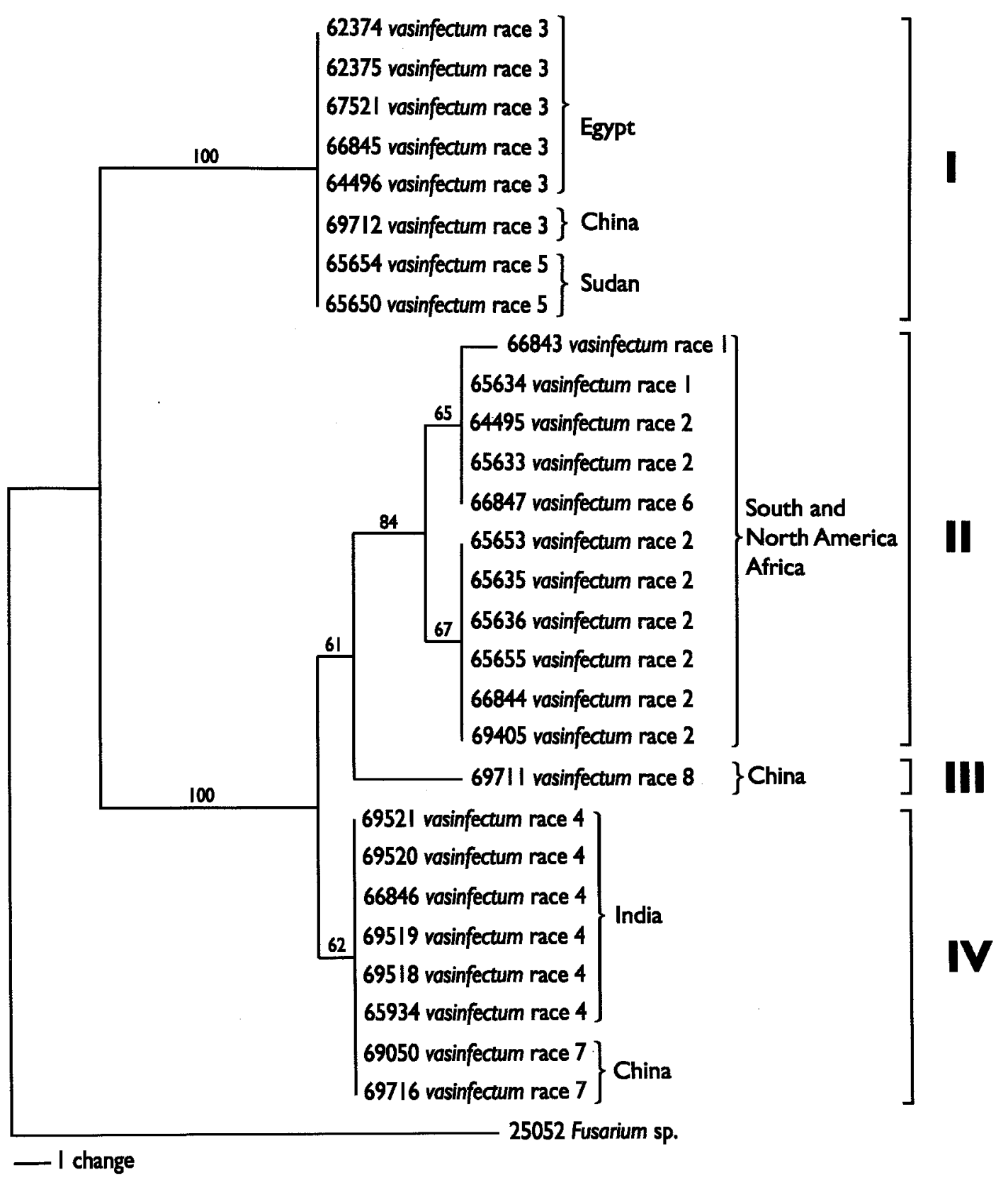

Fig. 3. Single most parsimonious tree inferred from combined analysis of translation elongation factor, mitochondrial small subunit rDNA, nitrate reductase, and phosphate permase gene sequences. Bootstrap frequencies of $\geq 50 \%$ from 1,000 parsimony replications are shown above each node. Four lineages (I to IV) of $F$. oxysporum f. sp. vasinfectum races are identified by brackets. Tree length $=38$ steps, consistency index $=1$, retention index $=1$. 
and 8 also resulted in significantly longer trees $(P=0.0253)$. However, a constraint forcing the monophyly of race 2 yielded three trees that were only one step longer and not significantly different from the MPT $(P=0.3175)$.

\section{DISCUSSION}

We were able to reject the hypothesis of a monophyletic origin of the forma specialis vasinfectum. The molecular phylogeny indicate that the eight races of $F$. oxysporum $\mathrm{f}$. sp. vasinfectum with pathogenicity toward cotton represent at least two independent evolutionary origins (Fig. 4). Polyphyly of $F$. oxysporum f. sp. cubense, which is composed of at least five distinct lineages, has also been reported (26). All of the polyphyletic

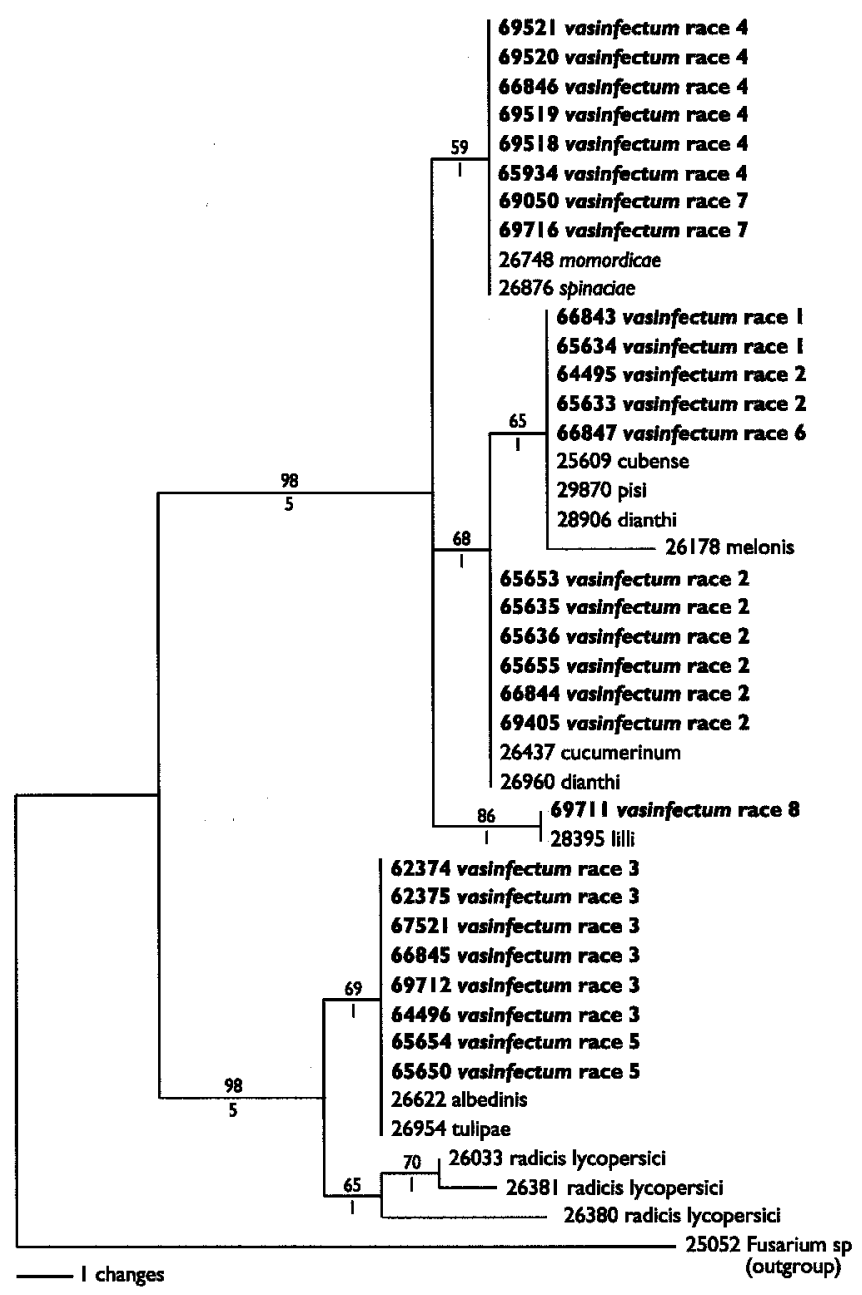

Fig. 4. Single most parsimonious tree 36 steps in length (consistency index $=$ 1 , retention index $=1$ ) inferred from the combined analysis of mitochondrial small subunit rDNA and translation elongation factor gene sequences. Bootstrap frequencies from 1,000 replications of $\geq 50 \%$ are given above nodes. Decay indices are indicated below nodes. formae speciales identified to date $(7,26)$ are composed of two or more vegetative compatibility groups (VCGs). Consistent with this finding, at least 10 different VCGs have been reported within F. oxysporum f. sp. vasinfectum $(11,17)$. By comparison, the two monophyletic formae speciales identified by Baayen et al. (7), lilii and tulipae, are both composed of a single VCG.

The combined EF- $1 \alpha$, mtSSU rDNA, PHO, and NIR sequence data for the 28 isolates of $F$. oxysporum f. sp. vasinfectum possessed enough phylogenetically informative sites to recover four lineages that correlated with differences in virulence and geographic origin (Fig. 3). Lineage $I$ is composed of race 3 and 5 primarily from the Nile region, Africa (bootstrap $=100 \%$ ). Although Ibrahim (15) reported that these two races could be differentiated by pathogenicity to cotton alone, we were unable to distinguish races 3 and 5 with the loci sequenced in the present study. In addition, attempts to distinguish these two races by fatty acid profiles (13), morphological characters, and pathogenicity tests (23) were unsuccessful. These findings suggest that races 3 and 5 might be combined, because pathogenicity tests cannot be used to distinguish them reliably.

Lineage II is composed of races 1, 2, and 6 reported from the United States, South America, and most of Africa (2,5). All of these races infect upland cotton, $G$. hirsutum, and are only separated by their ability to cause wilt symptoms on soybean and tobacco. Based on pathogenicity tests on five cotton cultivars and RAPD profiles, Assigbetse et al. (6) combined races 1, 2, and 6 into a single race, separate from races 3 and 4 . However, differences in growth and pigment production of races 1 and 2 on aesculin agar $(8,28)$, as well as differences in their ability to cause wilt on tobacco cv. Gold Dollar (30), suggests that these two races should be maintained. Race 8 from China (9) represents a distinct lineage within the molecular phylogeny, whereas race 7, also from China, is genetically indistinguishable from the race 4 isolates from India. However, isolates of races 4 and 7 can be separated by their pathogenicity toward $G$. barbadense and $G$. hirsutum $(2,9)$.

In the present study, no DNA polymorphism was detected within multiple isolates of races $3,4,5$, and 7. This is consistent with the results obtained by Assigbetse et al. (6) who reported that only one RAPD profile was detected in 12 isolates of race 3 , and another profile was shared by nine isolates of race 4 . In another study (17), 386 isolates of $F$. oxysporum f. sp. vasinfectum race 3 were all shown to belong to the same VCG, further suggesting that only minor genetic variation exists within this race.

The race structure within other formae speciales of $F$. oxysporum is often complex and sometimes not resolved by molecular markers $(1,19,21)$. Woo et al. (33) reported that RAPD and RFLP banding patterns did not correlate with the different races of $F$. oxysporum $\mathrm{f}$. sp. phaseoli. In addition, within $F$. oxysporum $\mathrm{f}$. sp. vasinfectum, Fernandez et al. (11) did not find a strict correlation between race and rDNA RFLP profiles. In contrast, Assigbetse et al. (6) identified RAPD markers that could be used to distinguish three races of $F$. oxysporum f. sp. vasinfectum. Baayen et al. (7) was able to distinguish races of $F$. oxysporum $\mathrm{f}$. sp. dianthi using EF- $1 \alpha$ and mtSSU rDNA sequence data. The four loci sampled in the present study could differentiate most of the $F$. oxysporum $\mathrm{f}$. sp. vasinfectum races at different levels. With the exception of

TABLE 3. Kishino-Hasegawa analysis of combined mitochondrial small subunit rDNA and translation elongation factor data

\begin{tabular}{lcccc}
\hline Tree $^{\mathrm{a}}$ & Tree length & Length difference & SD $^{\mathrm{b}}$ & $t$ \\
\hline Most parsimonious tree (MPT) & 36 & Best & $\ldots$ & $\ldots$ \\
Fusarium oxysporum f. sp. vasinfectum monophyly enforced & 50 & 14 & 3.723 & 3.760 \\
F. oxysporum f. sp. vasinfectum race 1, 2, 4, 6, 7, and 8 monophyly enforced & 41 & $0.0002^{*}$ \\
F. oxysporum f. sp. vasinfectum race 2 monophyly enforced & 37 & 5 & 2.233 & 2.239 \\
\hline
\end{tabular}

${ }^{a}$ Monophyly constraints enforced with phylogenetic analysis using parsimony (PAUP 4.0b.4a; Sinauer Associates Inc., Sunderland, MA).

b Standard deviation of $\log$ likelihood.

c Probability of getting a more extreme $t$ value under the null hypothesis of no difference between the MPT and the constrained tree, using a two-tailed test.

Asterisked values indicate significant difference at $P<0.05$. 
races 4 and 7 , sequences of EF- $1 \alpha$ and PHO were able to distinguish isolates of $F$. oxysporum $\mathrm{f}$. sp. vasinfectum corresponding to virulence toward different cotton species. Further, the mtSSU rDNA genealogy (Fig. 2B) separated the F. oxysporum f. sp. vasinfectum isolates into two groups that correlated with conidial morphology. Isolates of races 3 and 5 can be separated easily from the other races by their significantly smaller conidia (23). Although the NIR sequences possessed the least phylogenetic signal of the four loci sequenced, the $F$. oxysporum $\mathrm{f}$. sp. vasinfectum isolates formed three clusters within the NIR gene tree (Fig. 2C) that generally correlated with their geographic origin: races 3 and 5 primarily from the Nile region, Africa; races 1, 2, and 6 mostly from South and North America; and races 4, 7, and 8 from Asia. Overall, sequences of EF-1 $\alpha$ proved to be the most informative, contributing close to $40 \%$ of the phylogenetic signal, which suggests that this marker represents a valuable molecular systematic tool for resolving phylogenetic relationships within $F$. oxysporum (26) and other related phytopathogenic fungi (27).

Results of the present work demonstrate the polyphyly of $F$. oxysporum f. sp. vasinfectum, because races 3 and 5 appear to have evolved independently of the six other races. This molecular phylogenetic study provides an evolutionary context in which differences in pathogenicity between the two major groups of $F$. oxysporum f. sp. vasinfectum races can be further investigated.

\section{ACKNOWLEDGMENTS}

We thank L. Fabricius for assistance in preparing the figures and the curators of the culture collections for providing strains. The USDA neither guarantees nor warrants the standard of the product, and the use of the name USDA implies no approval of the product to the exclusion of others that may also be suitable.

\section{LITERATURE CITED}

1. Appel, D. J., and Gordon, T. R. 1996. Relationships among pathogenic and nonpathogenic isolates of Fusarium oxysporum based on the partial sequence of the intergenic spacer region of the ribosomal DNA. Mol. Plant-Microbe Interact. 9:125-139.

2. Armstrong, G. M., and Armstrong, J. K. 1960. American, Egyptian, and Indian cotton-wilt Fusaria: Their pathogenicity and relationship to other wilt fusaria. U.S. Dep. Agric. Tech. Bull. 219.

3. Armstrong, G. M., and Armstrong, J. K. 1978. A new race (race 6) of the cotton-wilt Fusarium from Brazil. Plant Dis. Rep. 62:421-423.

4. Armstrong, G. M., and Armstrong, J. K. 1981. Formae speciales and races of Fusarium oxysporum causing wilt diseases. Pages 391-399 in: Fusarium: Diseases, Biology, and Taxonomy. P. E. Nelson, T. A. Toussoun, and R. J. Cook, eds. The Pennsylvania State University Press, University Park, PA.

5. Armstrong, J. K., and Armstrong, G. M. 1958. A race of the cotton wilt Fusarium causing wilt of Yelredo soybean and flue-cured tobacco. Plant Dis. Rep. 42:147-151.

6. Assigbetse, K. B., Fernandez, M. P., and Geiger, J. P. 1994. Differentiation of Fusarium oxysporum $\mathrm{f}$. sp. vasinfectum races on cotton by random amplified polymorphic DNA (RAPD) analysis. Phytopathology 84:622-626.

7. Baayen, R. P., O’Donnell, K., Bonants, P. J. M., Cigelnik, E., Kroon, L. P. N. M., Roebroeck, E. J. A., and Waalwijk, C. 2000. Gene genealogies and AFLP analyses in the Fusarium oxysporum complex identify monophyletic and nonmonophyletic formae speciales causing wilt and rot disease. Phytopathology 90:891-900.

8. Bridge, P. D., Ismail, M. A., and Rutherford, M. A. 1993. An assessment of aesculin hydrolysis, vegetative compatibility and DNA polymorphism as criteria for characterizing pathogenic races within Fusarium oxysporum f. sp. vasinfectum. Plant Pathol. 42:264-269.

9. Chen, Q., Ji, X., and Sun, W. 1985. Identification of races of cotton wilt Fusarium in China. Agric. Sci. China 6:1-6.

10. Davis, R. D., Moore, N. Y., and Kochman, J. K. 1996. Characterisation of a population of Fusarium oxysporum $\mathrm{f}$. sp. vasinfectum causing wilt of cotton in Australia. Aust. J. Agric. Res. 47:1143-1156.

11. Fernandez, D., Assigbetse, K., Dubois, M., and Geiger, J. P. 1994. Molecular characterization of races and vegetative compatibility groups in
Fusarium oxysporum f. sp. vasinfectum. Appl. Environ. Microbiol. 60:4039-4046.

12. Geiser, D. M., Pitt, J. L., and Taylor, J. W. 1998. Cryptic speciation and recombination in the aflatoxin producing fungus Aspergillus flavus. Proc. Natl. Acad. Sci. USA 95:388-393.

13. Hering, O., Nirenberg, H. I., Koehn, S., and Deml, G. 1999. Characterization of isolates of Fusarium oxysporum Schlecht. f. sp. vasinfectum (Atk.) Snyd. \& Hans., races 1-6, by cellular fatty acid analysis. J. Phytopathol. 147:509-514.

14. Hillocks, R. J. 1984. Production of cotton varieties with resistance to Fusarium wilt with special reference to Tanzania. Trop. Pest Manag. 30:234-246.

15. Ibrahim, F. M. 1966. A new race of the cotton-wilt Fusarium in the Sudan Gezira. Emp. Cotton Grow. Rev. 43:296-299.

16. Ibrahim, G., and Nirenberg, H. I. 1993. Response of some Sudanese cotton cultivars to race 1 and 5 of Fusarium oxysporum f. sp. vasinfectum. Z. Pflanzenkr. Pflanzenschutz 100:645-651.

17. Katan, T., and Katan, J. 1988. Vegetative-compatibility grouping of Fusarium oxysporum f. sp. vasinfectum from tissue and the rhizosphere of cotton plants. Phytopathology 78:852-855.

18. Kelly, A., Alcalá-Jiménez, A. R., Bainbridge, B. W., Heale, J. B., PérezArtés, E., and Jiménez-Díaz, R. M. 1994. Use of genetic fingerprinting and random amplified polymorphic DNA to characterize pathotypes of Fusarium oxysporum f. sp. ciceris infecting chickpea. Phytopathology 84:1293-1298.

19. Kistler, H. C. 1997. Genetic diversity in the plant-pathogenic fungus Fusarium oxysporum. Phytopathology 87:474-479.

20. Koufopanou, V., Burt, A., and Taylor, J. W. 1997. Concordance of gene genealogies reveals reproductive isolation in the pathogenic fungus Coccidioides immitis. Proc. Natl. Acad. Sci. USA 94:5478-5482.

21. Manicom, B. Q., and Baayen, R. P. 1993. Restriction fragment length polymorphisms in Fusarium oxysporum f. sp. dianthi and other fusaria from Dianthus species. Plant Pathol. 42:851-857.

22. Moricca, S., Ragazzi, A., Kasuga, T., and Mitchelson, K. R. 1998. Detection of Fusarium oxysporum $\mathrm{f}$. sp. vasinfectum in cotton tissue by polymerase chain reaction. Plant Pathol. 47:486-494.

23. Nirenberg, H. I., Ibrahim, G., and Michail, S. H. 1994. Race identity of three isolates of Fusarium oxysporum Schlecht. f. sp. vasinfectum (Atk.) Snyd. and Hans. from Egypt and the Sudan. Z. Pflanzenkr. Pflanzenschutz 101:594-597.

24. O’Donnell, K., and Cigelnik, E. 1997. Two divergent intragenomic rDNA ITS2 types within a monophyletic lineage of the fungus Fusarium are nonorthologous. Mol. Phylogenet. Evol. 7:103-116.

25. O’Donnell, K., Cigelnik, E., and Nirenberg, H. I. 1998. Molecular systematics and phylogeography of the Gibberella fujikuroi species complex. Mycologia 90:465-493.

26. O’Donnell, K., Kistler, H. C., Cigelnik, E., and Ploetz, R. C. 1998. Multiple evolutionary origins of the fungus causing Panama disease of banana: Concordant evidence from nuclear and mitochondrial gene genealogies. Proc. Natl. Acad. Sci. USA 95:2044-2049.

27. O'Donnell, K., Kistler, H. C., Tacke, B. K., and Casper, H. H. 2000. Gene genealogies reveal global phylogeographic structure and reproductive isolation among lineages of Fusarium graminearum, the fungus causing wheat scab. Proc. Natl. Acad. Sci. USA 97:7905-7910.

28. Rutherford, M. A., Paterson, R. R. M., Bridge, P. D., and Brayford, D. 1993. Coumarin utilization patterns of pathogenic races of Fusarium oxysporum causing vascular wilt on cotton. J. Phytopathol. 138:209-216.

29. Shi, J., Mueller, W. C., and Beckman, C. H. 1992. Vessel occlusion and secretory activities of vessel contact cells in resistant or susceptible cotton plants infected with Fusarium oxysporum f. sp. vasinfectum. Physiol. Mol. Plant Pathol. 40:133-147.

30. Smith, S. N., Ebbels, D. L., Garger, R. H., and Kappelman, A. J. 1981. Fusarium wilt of cotton. Pages 29-38 in: Fusarium: Diseases, Biology, and Taxonomy. P. E. Nelson, T. A. Toussoun, and R. J. Cook, eds. The Pennsylvania State University Press, University Park, PA.

31. Taylor, J. W., Jacobson, D. J., Kroken, S., Kasuga, T., Geiser, D. M., Hibbett, D. S., and Fisher, M. C. 2001. Phylogenetic species recognition and species concepts in fungi. Fungal Genet. Biol. 21:21-32.

32. White, T. J., Bruns, T., Lee, S., and Taylor, J. 1990. Amplification and direct sequencing of fungal ribosomal RNA genes for phylogenetics. Pages 315-322 in: PCR Protocols: A Guide to Methods and Applications. M. A. Innes, D. H. Gelfand, J. J. Sninsky, and T. J. White, eds. Academic Press, San Diego, CA.

33. Woo, S. L., Zoina, A., Del Sorbo, G., Lorito, M., Nanni, B., Scala, F., and Noviello, C. 1996. Characterization of Fusarium oxysporum f. sp. phaseoli by pathogenic races, VCGs, RFLPs, and RAPD. Phytopathology 86:966-973. 